\title{
Human amniotic fluid stem cells do not differentiate into dopamine neurons in vitro or after transplantation in vivo.
}

\author{
Angela E Donaldson \\ Department of Neurology, Farber Institute for the Neurosciences, Thomas Jefferson University \\ Jingli Cai \\ Department of Neurology, Farber Institute for the Neurosciences, Thomas Jefferson University \\ Ming Yang \\ Department of Neurology, Farber Institute for the Neurosciences, Thomas Jefferson University \\ Lorraine lacovitti \\ Department of Neurology, Farber Institute for the Neurosciences, Thomas Jefferson University
}

Follow this and additional works at: https://jdc.jefferson.edu/farberneursofp

Part of the Neurology Commons

Let us know how access to this document benefits you

\section{Recommended Citation}

Donaldson, Angela E; Cai, Jingli; Yang, Ming; and lacovitti, Lorraine, "Human amniotic fluid stem cells do not differentiate into dopamine neurons in vitro or after transplantation in vivo." (2009). Farber Institute for Neurosciences Faculty Papers. Paper 7.

https://jdc.jefferson.edu/farberneursofp/7

This Article is brought to you for free and open access by the Jefferson Digital Commons. The Jefferson Digital Commons is a service of Thomas Jefferson University's Center for Teaching and Learning (CTL). The Commons is a showcase for Jefferson books and journals, peer-reviewed scholarly publications, unique historical collections from the University archives, and teaching tools. The Jefferson Digital Commons allows researchers and interested readers anywhere in the world to learn about and keep up to date with Jefferson scholarship. This article has been accepted for inclusion in Farber Institute for Neurosciences Faculty Papers by an authorized administrator of the Jefferson Digital Commons. For more information, please contact: JeffersonDigitalCommons@jefferson.edu. 


\title{
Human Amniotic Fluid Stem Cells Do Not Differentiate Into Dopamine Neurons In Vitro or After Transplantation In Vivo
}

\author{
Angela E. Donaldson, Jingli Cai, Ming Yang, and Lorraine lacovitti
}

\begin{abstract}
Although embryonic stem (ES) cells can generate dopamine (DA) neurons that are potentially useful as a cell replacement therapy in Parkinson's disease (PD), associated ethical and practical concerns remain major stumbling blocks to their eventual use in humans. In this study, we examined human amniotic fluid stem (hAFS) cells derived from routine amniocenteses for their potential to give rise to DA neurons in vitro and following transplantation into the 6-hydroxydopamine-lesioned rat brain. We show that undifferentiated hAFS cells constitutively expressed mRNAs and proteins typical of stem cells but also cell derivatives of all three germ layers, including neural progenitors/neurons (nestin, $\beta$-tubulin III, neurofilament). Additionally, these cells expressed mRNAs of an immature DA phenotype (Lmx1a, Pitx-3, Nurr1, Aldh1a1) but not the corresponding proteins. Importantly, treatment with DA differentiation factors using a variety of protocols did not further promote the development of fully differentiated DA neurons from hAFS cells. Thus, Lmx1a, Aldh1a1, AADC, TH, and DAT proteins were not detected in hAFS cells in culture or after transplantation into the PD rat brain. Moreover, by 3 weeks after implantation, there were no surviving AFS cells in the graft, likely as a result of an acute immunorejection response, as evidenced by the abundant presence of CD11+ macrophage/microglia and reactive GFAP+ astrocytes in the host brain. Taken together, these results suggest that further studies will be needed to improve differentiation procedures in culture and to prolong cell survival in vivo if hAFS cells are to be useful as replacement cells in PD.
\end{abstract}

\section{Introduction}

$\mathrm{O}$ VER THE LAST TWO decades, there has been intense focus on the potential use of stem cells to replace dead or dying neurons in neurodegenerative diseases such as Parkinson's disease (PD). Toward this end, stem cells from a variety of embryonic and adult sources have been studied in vitro and in vivo using a host of differentiation protocols (for review, refs. 1,2). To date, partial success has been achieved. While adult human bone marrow stromal stem cells (hMSCs) are capable of acquiring some dopaminergic traits, they do not fully trans-differentiate into dopamine (DA) neurons nor do they survive long term transplantation into the brain [3]. Greater success has instead been achieved using human embryonic stem (hES) cells that can be differentiated into neurons of a DA phenotype in vitro and in vivo, and which can ameliorate motor deficits after transplantation into an animal model of PD [4-14].

However, ongoing legal, ethical, and practical issues associated with ES cells remain major stumbling blocks to their eventual use in humans. Consequently, researchers continue to search for more practical sources of stem cells in humans. One such alternative source that has received much interest of late is human amniotic fluid collected during routine amniocenteses. Amniotic fluid contains a variety of cell types derived from both fetal and amnion tissues, $\sim 1 \%$ of which are believed to be amniotic fluid stem (AFS) cells $[15,16]$. Thus, it was of great interest when Atala and colleagues [17] reported recently that they had successfully established human stem cell lines from amniotic fluid (hAFS). These hAFS cells were capable of unlimited self-renewal and differentiation into derivatives of all three germ layers in culture, sharing overlapping but not identical properties with pluripotent hES cells [17]. Of particular significance, was their ability to express traits of a neural lineage (i.e., nestin and $\beta$-tubulin III) in culture and after transplantation into the brain. Unlike their hES cell counterparts, hAFS cells reportedly showed no sign of tumorigenicity in vivo. Thus, hAFS cell lines could provide an abundant,

Department of Neurology, Farber Institute for the Neurosciences, Thomas Jefferson University, Philadelphia, Pennsylvania. 
nontumor-forming source of human stem cells free of ethical dilemma that could be used in cell replacement therapies for diseases like PD. Therefore, in this study, we investigated whether cells derived from hAFS cell lines could indeed be differentiated into neurons, particularly those that express traits of a DA phenotype either in vitro or after transplantation in vivo into $\mathrm{PD}$ rats.

\section{Materials and Methods}

\section{Cell propagation/differentiation in culture}

Cells of the AFS-A1 (Passage 15) and AFS-H1 (Passage 18) cells lines were generously supplied by A. Atala (Wake Forest University, NC). Human AFS cells were cultured on polystyrene (Petri) dishes in $\alpha$-MEM medium (Invitrogen) containing 18\% Chang's Medium B, 2\% Chang's Medium C (Irvine Scientific), ES-qualified 15\% FBS (Invitrogen), 1\% L-glutamine and 1\% Penicillin/Streptomycin (Invitrogen) at $37^{\circ} \mathrm{C}$ with $5 \% \mathrm{CO}_{2}$ atmosphere. Cells were passaged at $70 \%$ confluence at a dilution of 1:4 to 1:6 and used for experiments at Passage 15-21 for A1 cells and Passage 18-27 for H1 cells. For differentiation protocols, cells were grown either according to Protocol A in defined serum-free (DM) media plus 20 $\mathrm{ng} / \mathrm{mL}$ of basic fibroblast growth factor (bFGF) for 1 week followed by 1 week in $10 \mathrm{ng} / \mathrm{mL}$ aFGF, $200 \mathrm{nM}$ TPA, $20 \mu \mathrm{M}$ DA, $0.25 \mathrm{mM}$ IBMX plus $50 \mu \mathrm{M}$ forskolin; or Protocol B as described in Results. Essentially, neurosphere-like clusters were generated from $5 \times 10^{5}$ cells grown in suspension in $\mathrm{DM}+$ Noggin $(200 \mathrm{ng} / \mathrm{mL}$ ) and maintained for 5-7 days (as described previously in ref. 6). Cells were gently lifted with a P1000 pipette and seeded in Ultra-low attachment dishes (Corning). In addition, cells were plated at a high density (100,000-150,000 cells in $25 \mu \mathrm{L}$ seeded droplet) on chamber slide wells coated with polyornithine, $100 \mathrm{ng} / \mathrm{cm}^{2}$ human collagen IV, $10 \mathrm{ng} / \mathrm{mL}$ laminin or $5 \mu \mathrm{g} / \mathrm{mL}$ human plasma fibronectin and incubated with a variety of other differentiation protocols (Table 2).

\section{6-OHDA lesions}

Animals were maintained in accord with the Office of Animal Resources at Thomas Jefferson University and IACUC policies. As described previously [14,18], 12 Fischer 344 rats (Taconic) were made Parkinsonian for these studies. Briefly, rats were anesthetized with sodium pentobarbital [30 mg/kg, intraperitoneally (i.p.)], placed in a stereotaxic apparatus (Kopf Instruments) and a 26-gauge Hamilton syringe containing 6-OHDA (Sigma; $20 \mu \mathrm{g} / \mathrm{mL}$ in $4 \mu \mathrm{L}$ phosphate-buffered saline (PBS) containing $0.2 \mathrm{mg} / \mathrm{mL}$ ascorbate) was lowered into the right median forebrain bundle (AP: $-4.4 \mathrm{~mm}$, ML: $-1.2 \mathrm{~mm}$, DV: $-7.8 \mathrm{~mm}$ from bregma). The 6-OHDA solution was gradually injected at a rate of $1 \mu \mathrm{L} / \mathrm{min}$. All lesions were verified 3 and 6 weeks later by assessment of rotational behavior in an automated rotometer system (Columbus Instruments) following amphetamine challenge (5 mg/kg, i.p.). Only rats with consistent and stable lesions ( $>10$ ipsilateral turns/min on multiple tests) were used for transplantation studies.

\section{Transplantation procedures}

Animals with verifiable lesions ( $>10$ ipsilateral turns/ min) were implanted with a total of $10 \mu \mathrm{L}$ of PBS containing $\sim 1 \times 10^{6}$ of undifferentiated $(N=4)$ or semi-differentiated [cells treated with bFGF in Protocol A $(N=2)$ or neurospheres generated in Protocol B $(N=8)$ ] hAFS cells, deposited at three stereotaxic levels (AP: $+1.2 \mathrm{~mm}, \mathrm{ML}:-2.7 \mathrm{~mm}$, DV: $-5.4 \mathrm{~mm},-4.9 \mathrm{~mm}$ and $-4.2 \mathrm{~mm}$ ) in the striatum on the side ipsilateral to the 6-OHDA lesion as described previously [13]. All transplant recipients received cyclosporine A (15 mg/kg, i.p.) daily, beginning 1-2 days before transplantation. Animals with hAFS cell transplants were sacrificed at 3 days, 1 and 3 weeks and brains sectioned for immunocytochemical analysis.

\section{Immunocytochemistry}

Cultures were rinsed twice in PBS, fixed with $4 \%$ paraformaldehyde and immunocytochemically stained (details described in 14). Antibodies used were: mouse monoclonal anti-Nestin (Chemicon 1:250), rabbit polyclonal anti-homeobox transcription factor 1 alpha (Lmx1; gift from Dr. M. German $1: 1,000)$, mouse monoclonal anti- $\beta$-tubulin III (R\&D Systems $1: 400)$, goat polyclonal anti-retinaldehyde dehydrogenase (Aldh1a1) (Novus Biologicals 1:500), rabbit polyclonal antityrosine hydroxylase (TH) (Pel-Freez 1:150), sheep polyclonal anti-TH (Abcam 1:1000), rabbit polyclonal anti-glial fibrillary acidic protein (GFAP) (Chemicon 1:1000), rabbit polyclonal antiaromatic L-amino acid decarboxylase (AADC) (Protos Biotech 1:50) mouse monoclonal anti-dopamine transporter (DAT) (Chemicon 1:50). All secondary antibodies were Alexa Fluor antibodies from Invitrogen; donkey anti-rabbit 594, 1:300; donkey anti-rabbit 488, 1:300; donkey anti-mouse 594, 1:300; donkey anti-mouse 488, 1:300.Cultures were mounted in ProLong Gold antifade reagent with DAPI (Invitrogen). Stained cells were counted in representative fields $(N=5)$ on duplicate slides and expressed as a percentage of the total cells.

For immunocytochemical staining in transplantation experiments, rats were perfused with $500 \mathrm{~mL}$ of cold $\left(4^{\circ} \mathrm{C}\right)$ periodate-lysine-paraformaldehyde (4\%). Brains sections were cut at $30 \mu \mathrm{m}$ on a freezing microtome and processed for immunocytochemistry as described previously [6,14]. Antibodies were used as above except for the following differences: ( $\beta$-tubulin III; 1:200), HNA (1:40); GFAP from Chemicon (1:200) and mouse monoclonal anti-CD11 from BD Biosciences (1:25). Brain sections were analyzed along the length of the graft using a Nikon-Scanalytics Image System or a Zeiss LSM510 Confocal Image System.

\section{RNA isolation and cDNA synthesis}

Total RNA was isolated directly from freshly collected hAFS neurospheres and H9 StgIV cells with TRIzol (Invitrogen), a modification of the guanidine isothiocyanatephenol-chloroform extraction method. cDNA was synthesized by using $100 \mathrm{ng}$ total RNA in a $20 \mu \mathrm{L}$ reaction with Superscript III (Invitrogen) and oligo (dT)12-18 (Invitrogen). One microliter of RNase H (Invitrogen) was added to each reaction tube, and the tubes were incubated for $20 \mathrm{~min}$ at $37^{\circ} \mathrm{C}$ before proceeding to polymerase chain reaction (PCR).

\section{PCR amplification}

A $0.5 \mu \mathrm{L}$ cDNA template was used in a $20 \mu \mathrm{L}$ reaction volume with the PCR master mix (Promega).The cycling parameters were: $94^{\circ} \mathrm{C}, 1 \mathrm{~min} ; 55^{\circ} \mathrm{C}, 1 \mathrm{~min} ; 72^{\circ} \mathrm{C}, 1 \mathrm{~min}$, for 
30 cycles. The PCR cycles were preceded by an initial denaturation of $3 \mathrm{~min}$ at $94^{\circ} \mathrm{C}$ and followed by a final extension of $10 \mathrm{~min}$ at $72^{\circ} \mathrm{C}$ (details in ref. 14) (primers are listed in Table 1).

\section{Results}

Undifferentiated hAFS cells were propagated as described previously [17]. We first tested various differentiation protocols (see Table 2 for complete list), beginning with several used successfully to differentiate DA neurons either from hMSCs [3] or hES cells [6] in our laboratory. Undifferentiated hAFS cells, grown according to the mesenchymal protocol (Protocol A) (Fig. 1A), were fed a defined media containing $20 \mathrm{ng} / \mathrm{mL}$ of bFGF for 1 week followed by an additional week in the DA differentiation cocktail (10 ng/mL aFGF, 200 nM TPA, $20 \mu \mathrm{M}$ DA, $0.25 \mathrm{mM}$ IBMX plus $50 \mu \mathrm{M}$ forskolin) as described previously $[3,18,19]$. This media often produced a high level of cell death after several days in culture, possibly due to the presence of potentially toxic substances like forskolin. Using the hES differentiation protocol developed in this laboratory (Protocol B) (Fig.1B), hAFS cells were first incubated with $200 \mathrm{ng} / \mathrm{mL}$ noggin for 4 days to promote the formation of clusters of neural progenitors. This stage was next followed by a 1 week expansion phase during which cells were propagated as neurospheres in suspension before plating as dissociated cells. Unlike hES cells, hAFS cells did not readily form compact spheres nor did they require subcloning, suggesting that the nestin ${ }^{+}$cells in these spheres were not dividing as robustly as in hES cell cultures. Finally, when hAFS neurospheres were dissociated into single cells for further differentiation in adherent cultures, we found poor attachment to substrates (polyornithine, laminin, fibronectin, collagen type IV) previously used to adhere other types of stem cells $[3,6,14,17]$. Adherence of a small number of dissociated neurosphere (Protocol B) hAFS cells only when polyornithine-coated dishes were also treated with fibronectin.

TABle 1. Primers

\begin{tabular}{|c|c|c|c|}
\hline Gene name & $\begin{array}{l}\text { Accession } \\
\text { no. }\end{array}$ & Primer sequence & $\begin{array}{l}\text { Product } \\
\text { size }(b p)\end{array}$ \\
\hline Oct4 & BC117435 & $\begin{array}{l}\text { CTTGCTGCAGAAGTGGGTGGAGGAA } \\
\text { CTGCAGTGTGGGTTTCGGGCA }\end{array}$ & 169 \\
\hline Sox2 & NM_003106 & $\begin{array}{l}\text { ATGCACCGCTACGACGTGA } \\
\text { CTTTTGCACCCCTCCCATTT }\end{array}$ & 437 \\
\hline Nestin & NM_006617 & $\begin{array}{l}\text { CAGCGTTGGAACAGAGGTTGG } \\
\text { TGGCACAGGTGTCTCAAGGGTAG }\end{array}$ & 389 \\
\hline Vimentin & NM_003380 & $\begin{array}{l}\text { GACACTATTGGCCGCCTGCAGGATGAG } \\
\text { CTGCAGAAAGGCACTTGAAAGC }\end{array}$ & 418 \\
\hline$\beta$ IIItubulin & NM_006086 & $\begin{array}{l}\text { GAACAGCACGGCCATCCAGG } \\
\text { CTTGGGGCCCTGGGCCTCCGA }\end{array}$ & 244 \\
\hline NEFH & NM_021076 & $\begin{array}{l}\text { TGCGGCGCCACCACCAG } \\
\text { GGCGGCCATCTCCCACTTG }\end{array}$ & 452 \\
\hline GFAP & NM_002055 & $\begin{array}{l}\text { GTGGGCAGGTGGGAGCTTGATTCT } \\
\text { CTGGGGCGGCCTGGTATGACA }\end{array}$ & 388 \\
\hline AFP & NM_001134 & $\begin{array}{l}\text { AAATACATCCAGGAGAGCCA } \\
\text { CTGAGCTTGGCACAGATCCT }\end{array}$ & 417 \\
\hline FN & NM_212482 & $\begin{array}{l}\text { TGTTATGGAGGAAGCCGAGGTTTT } \\
\text { CCCGATGCAGGTACAGTCCCAGAT }\end{array}$ & 150 \\
\hline Lmxla & AY078391 & $\begin{array}{l}\text { CTCAATTTAGTGTATGAAGAGG } \\
\text { CTACATTCTCTTGGCTGGAC }\end{array}$ & 372 \\
\hline Aldh1a1 & NM_000689 & $\begin{array}{l}\text { CTGAAATGTGACCCCCAAGT } \\
\text { TGACAAGCAGACATGACATCC }\end{array}$ & 280 \\
\hline Pitx3 & NM_005029 & $\begin{array}{l}\text { GGACTAGGCCCTACACACAGA } \\
\text { TCCGCGCACGTTTATTTC }\end{array}$ & 151 \\
\hline Nurr1 & NM_006186 & $\begin{array}{l}\text { GGCTGAAGCCATGCCTTGT } \\
\text { GTGAGGTCCATGCTAAACTTGACA }\end{array}$ & 150 \\
\hline Girk2 & NM_002240 & $\begin{array}{l}\text { CAACAATGGCCAAGCTGACA } \\
\text { TCCGATCTCGGCTGATGTG }\end{array}$ & 150 \\
\hline AADC & NM_000790 & $\begin{array}{l}\text { GGGACCACAACATGCTGCTC } \\
\text { CCACTCCATTCAGAAGGTGCC }\end{array}$ & 145 \\
\hline DAT & NM_001044 & $\begin{array}{l}\text { TCCATCAACTCCCTGACGAGCTTC } \\
\text { CTGGGCCGCTGCCCGGTCATCTGC }\end{array}$ & 500 \\
\hline $\mathrm{TH}$ & NM_199292 & $\begin{array}{l}\text { TCATCACCTGGTCACCAAGTT } \\
\text { GGTCGCCGTGCCTGTACT }\end{array}$ & 125 \\
\hline GAPDH & NM_002046 & $\begin{array}{l}\text { ACAGTCAGCCGCATCTTCTT } \\
\text { GACAAGCTTCCCGTTCTCAG }\end{array}$ & 259 \\
\hline
\end{tabular}


Table 2. Differentiation of Amniotic Fluid Stem (AFS) Cells Using Various Treatment Protocols

\begin{tabular}{|c|c|c|c|c|c|c|c|}
\hline Treatment & Nestin & $\operatorname{Lm} x 1 a$ & Sox 2 & Aldh1a1 & $\beta t u b I I I$ & $\mathrm{TH}$ & GFAP \\
\hline Undifferentiated AFS Cells & $2+$ & - & - & $1+$ & $1+$ & - & - \\
\hline Defined Media -7 div & $2-3+$ & - & - & $1+$ & $1+$ & - & - \\
\hline \multicolumn{8}{|l|}{ Protocol A } \\
\hline $\begin{array}{l}\mathrm{DM}+\mathrm{aFGF}+\mathrm{DA}+\mathrm{TPA}+\mathrm{IBMX}+\text { Forskalin }-7 \text { div } \\
\quad{ }^{*} \text { High cell death }\end{array}$ & $2+$ & - & - & $1+$ & $3+$ & - & - \\
\hline \multicolumn{8}{|l|}{$\begin{array}{l}\text { Protocol B } \\
\text { DM + Noggin }(200 \mathrm{ng} / \mathrm{mL})-5-7 \text { div } \\
\text { Lift as neurospheres and seed in ultra-low attachment dish }\end{array}$} \\
\hline \\
\hline $\mathrm{DM}+\mathrm{cAMP}(500 \mu \mathrm{M})+$ Ascorbate $-2 \mathrm{div}$ & $2+$ & - & - & - & $1+$ & - & - \\
\hline $\mathrm{DM}+\mathrm{bFGF}(20 \mathrm{ng} / \mathrm{mL})+\operatorname{Noggin}(200 \mathrm{ng} / \mathrm{mL})-7 \mathrm{div}$ & $4+$ & - & - & $2+$ & $1+$ & - & - \\
\hline \multicolumn{8}{|l|}{$\begin{array}{l}\mathrm{DM}+\mathrm{bFGF}(20 \mathrm{ng} / \mathrm{mL})-7 \mathrm{div} \\
\mathrm{DM}+\mathrm{SHH}(200 \mathrm{ng} / \mathrm{mL})+\mathrm{FGF} 8(100 \mathrm{ng} / \mathrm{mL})+\mathrm{bFGF} \\
\quad(20 \mathrm{ng} / \mathrm{mL})-7 \mathrm{div} \\
{ }^{*} \text { Cell death at } 5 \mathrm{div}\end{array}$} \\
\hline $\begin{array}{l}\text { NB media + B27 + SHH }(250 \mathrm{ng} / \mathrm{mL})+\text { FGF8 }(100 \mathrm{ng} / \mathrm{mL}) \\
\quad+\text { bFGF }(50 \mathrm{ng} / \mathrm{mL})-7 \mathrm{div}\end{array}$ & $3-4+$ & - & - & - & $1+$ & - & - \\
\hline $\begin{array}{l}\mathrm{DM}+\mathrm{B} 27+\mathrm{BDNF}(25 \mathrm{ng} / \mathrm{mL})+\text { forskolin }(15 \mu \mathrm{M})+ \\
\mathrm{DA}(10 \mu \mathrm{M})-7 \text { div } \\
{ }^{*} \text { No change in morphology }\end{array}$ & $2+$ & & & & & & \\
\hline $\mathrm{DM}+\mathrm{B} 27+$ Wnt1 $(10 \mathrm{ng} / \mathrm{mL})+\mathrm{bFGF}(20 \mathrm{ng} / \mathrm{mL})-7 \mathrm{div}$ & $4+$ & - & - & - & $1+$ & - & \\
\hline $\begin{array}{l}\mathrm{DM}+\mathrm{B} 27+\text { ascorbate }(200 \mu \mathrm{M})+\mathrm{cAMP}(500 \mu \mathrm{M}) \\
{ }^{*} \text { High cell death }\end{array}$ & $2+$ & - & - & - & - & - & \\
\hline \multicolumn{8}{|l|}{$\begin{array}{l}\mathrm{DM}+\text { aFGF }+\mathrm{DA}+\mathrm{TPA}+\mathrm{IBMX}+\text { Forskalin }-7 \text { div } \\
{ }^{*} \text { Cells died within } 5 \text { div }\end{array}$} \\
\hline $\begin{array}{l}\mathrm{DM}+\text { bFGF }(20 \mathrm{ng} / \mathrm{mL})+\text { Wnt5A }(100 \mathrm{ng} / \mathrm{mL})-7 \mathrm{div} \\
{ }^{*} \text { Nestin + FoxA2 double-labeled cells }(1-2+)\end{array}$ & $4+$ & - & - & - & $1+$ & - & \\
\hline $\begin{array}{l}\mathrm{DM}+\text { substantia nigra conditioned media }(1: 1)-7 \text { div } \\
{ }^{*} \text { No change in cells }\end{array}$ & $2+$ & - & - & - & - & - & \\
\hline $\begin{array}{l}\mathrm{DM}+\text { glial conditioned media }(1: 1)-7 \text { div } \\
{ }^{*} \text { No change in cells }\end{array}$ & $2+$ & - & - & - & - & - & \\
\hline \multicolumn{8}{|l|}{$\begin{array}{l}\mathrm{DM}+\mathrm{H} 9 \text { stg } 5 \text { conditioned media }(1: 1) \\
{ }^{*} \text { Cells died within } 4-5 \text { days }\end{array}$} \\
\hline $\begin{array}{l}\mathrm{DM}+\mathrm{MEF} \text { conditioned media }(1: 1)-7 \text { div } \\
{ }^{*} \text { No change in cells }\end{array}$ & $2+$ & - & - & - & - & - & \\
\hline
\end{tabular}

AFS cells were stained for the presence of cell type specific markers after differentiation using a particular treatment protocol. For cultures treated with conditioned media, defined media was incubated for 3 days on cultures of P1 rat glia, E14 rat substantia nigra, mouse embryonic fibroblasts (MEF from specialty media), and stage V hES cells as described in ref. 6. Cultures of viable cells were stained with the markers listed and evaluated for the intensity of staining as follows: none (-), lightly (1+), moderately (2-3+), or darkly $(4+)$ stained cells.

To assess the degree of differentiation achieved by these cells at various stages in these treatment protocols, we next examined the expression of stem cell (Oct4, Sox2), neural progenitor (nestin, vimentin), neural [ $\beta$-tubulin III, neurofilament (NEFP)] glial (GFAP), endodermal $[\alpha$-fetoprotein (AFP)] and mesodermal (fibronectin:FN) markers as well as specific markers of the DA system, including the DA transcription factors (Lmx1a, Nurr1, Pitx3), enzymes (Aldh1a1, AADC, TH), transporters (DAT) and channels [G-protein regulated inwardly rectifying potassium channel (Girk2)] by PCR. We found that undifferentiated hAFS cells expressed not only stem cell transcripts, but also markers of the three germ layers, including those associated with an endodermal (AFP), mesodermal (FN) and neurectodermal lineage (nestin, $\beta$-tubulin III, human NEFH). Of particular interest was expression of mRNAs normally associated with more differentiated neuronal phenotypes (Fig. 2). Consequently, early markers of a DA phenotype, such as Lmx1a and Aldh1a1, 
A Protocol A

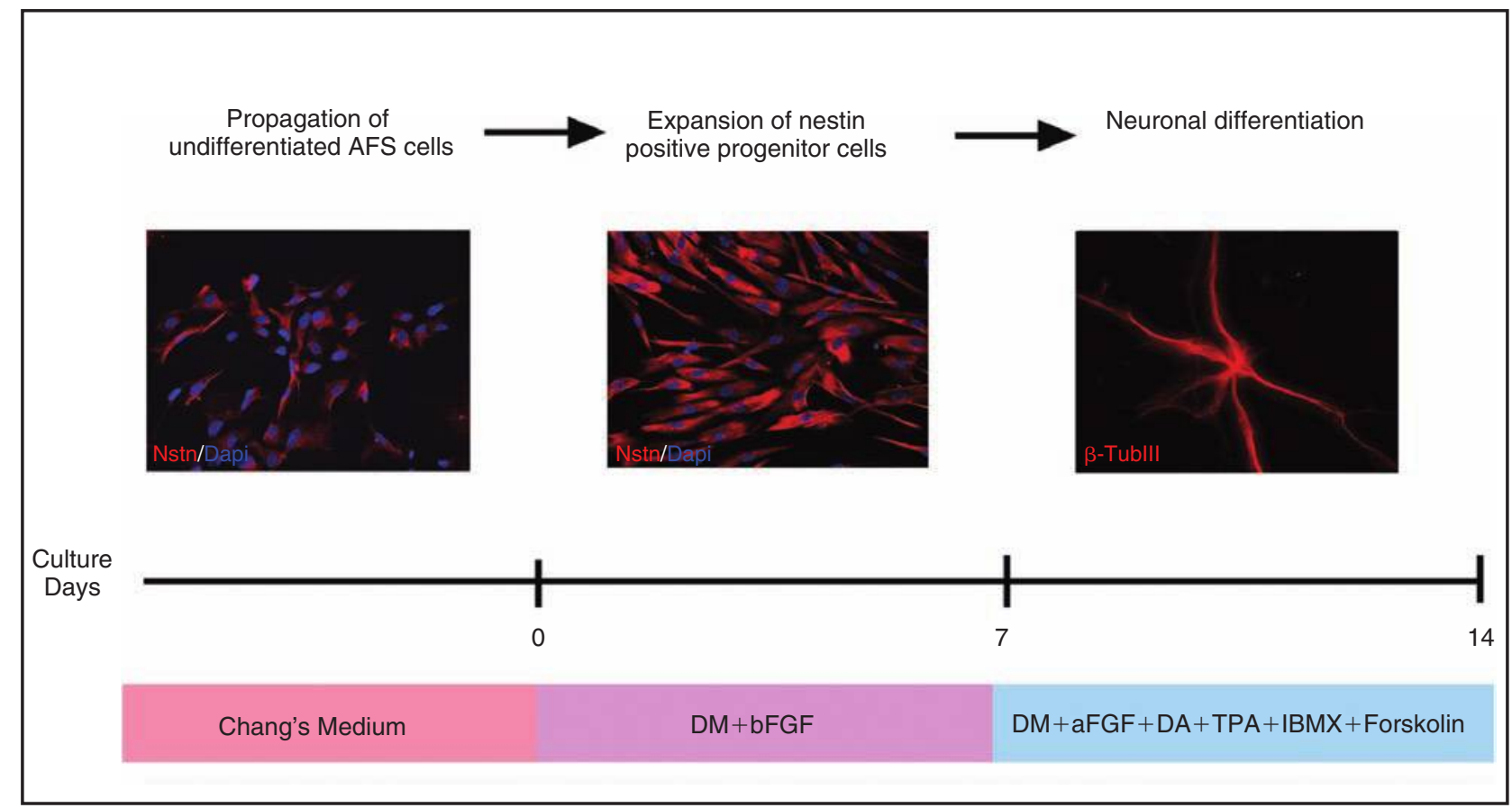

B Protocol B

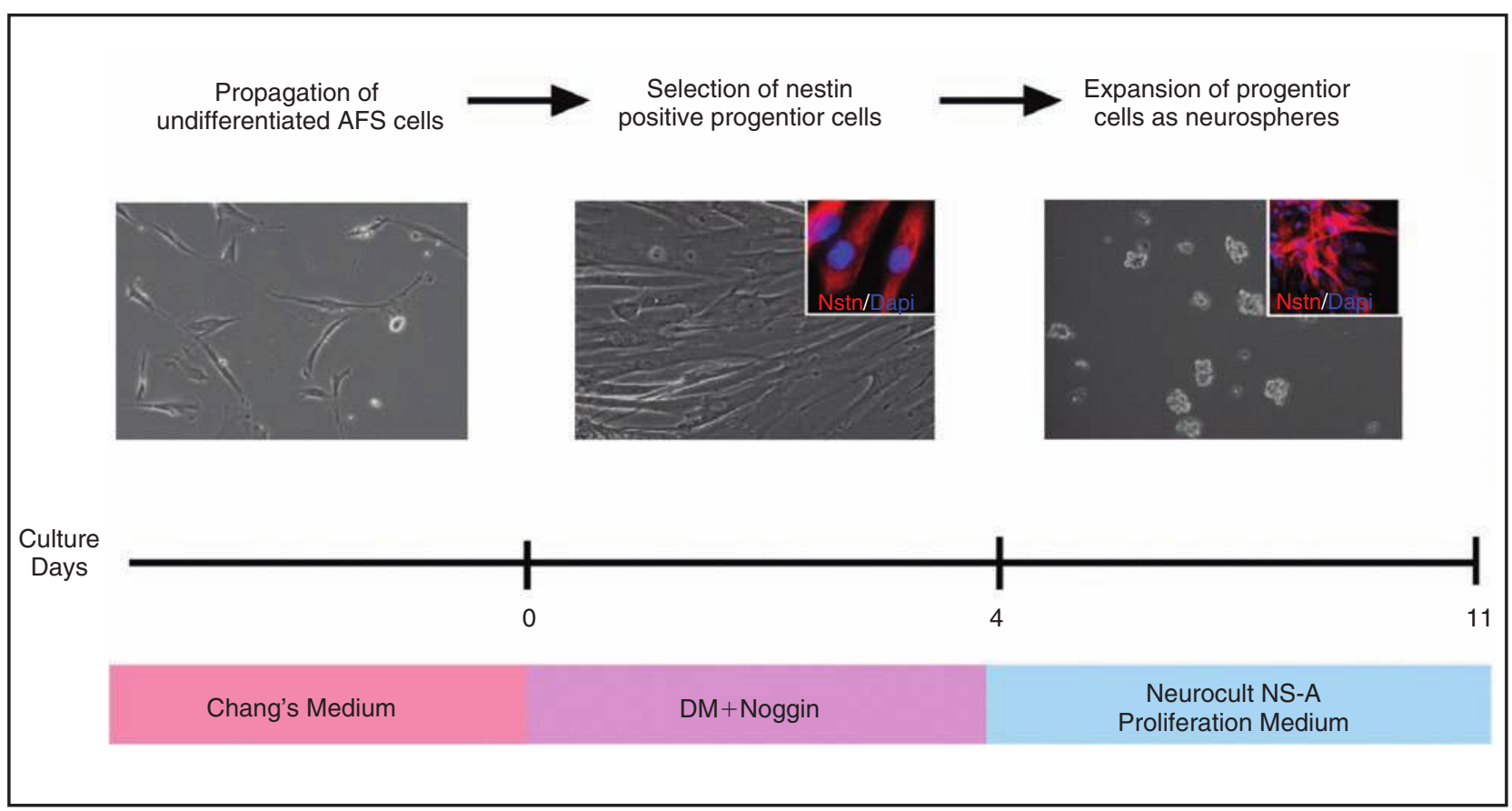

FIG. 1. Depiction of various treatments used to differentiate human amniotic fluid stem (hAFS) cells into dopamine (DA) neurons in culture. (A) Protocol A was previously used to differentiate DA neurons from human mesenchymal stem cells (hMSCs) and was described in detail in ref. 3. (B). Protocol B was previously used to differentiate DA neurons from hES cells and was described in ref. 6 .

were readily detected by reverse transcription (RT)-PCR while more mature DA markers (AADC, TH, DAT) were not. When hAFS cells were further differentiated by either protocol, we continued to see many of the same transcripts as in the undifferentiated state, with the exception of the disappearance of the endodermal marker AFP (Fig. 2). In addition, with Protocol A, the stem cell marker Oct 4 and the
DA-specifying gene Lmxla were down regulated (Fig. 2). However, hAFS neurospheres generated in Protocol B continued to express Lmxla as well as several other transcripts associated with a more differentiated DA phenotype (i.e., Pitx3, Nurr1 and Girk2; Fig. 2).

Next, sister cultures were stained with antibodies to many of these cell types and DA-specific markers. Similar 


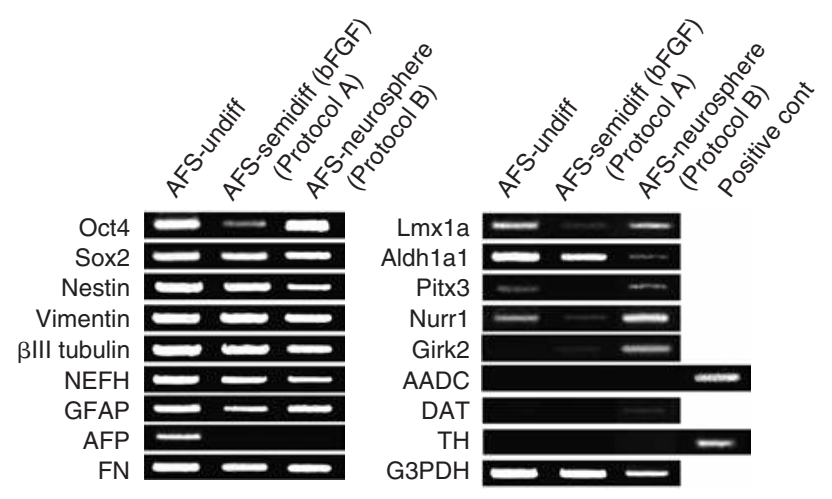

FIG. 2. RT-PCR analysis of various stages in human amniotic fluid stem (hAFS) cell differentiation. Markers of stem cells (Oct4, Sox2), neural progenitors (nestin, vimentin), neurons ( $\beta$ IIItubulin, NEFH), glia (GFAP), ectoderm (AFP), mesoderm (FN), as well as DA-related markers (Lmx1a, Aldh1a1, Pitx3, Nurr1, Girk2, AADC, DAT, TH) were compared in undifferentiated (AFS-undiff) or partially differentiated cells (AFS-semidiff with bFGF according to Protocol A) or following neurosphere formation (in Protocol B). Positive controls taken from human embryonic stem (hES) cells differentiated into DA neurons (as described in ref. 14) were also included for AADC and TH as these were not expressed in AFS cells.

to our RT-PCR results, using immunocytochemistry, we found that progenitor protein nestin was robustly expressed in $20-40 \%$ of individual undifferentiated hAFS cells (Fig. 1A, 1B insets; Table 2). With further differentiation, cells changed in morphological shape but continued to express nestin. Moreover, the proportion of nestin ${ }^{+}$cells increased, with the greatest number $(>80 \%)$ found in semi-differentiated cultures (Protocol A) and in neurospheres (Protocol B) (Table 2). In contrast, relatively few $(<20 \%)$ undifferentiated or semi-differentiated hAFS cells expressed the early neuron marker $\beta$-tubulin III (Fig. 3). The number of $\beta$-tubulin $\mathrm{III}^{+}$ cells did however increase (40-60\%) after the final differentiation step in Protocol A. Because in Protocol B dissociated neurosphere cells did not attach well to adherent substrates, we could not assess the degree of neuronal differentiation in these cultures (Table 2).

When semi-differentiated or fully differentiated cultures were further probed for the expression of DA marker proteins, importantly, no positively stained cells were observed regardless of their state of differentiation or the protocol used (Table 2). Thus, Lmx1a-staining cells were not detected by immunocytochemistry in these cultures despite detection of Lmxla mRNA in pooled cell cultures. Likewise, neither Aldh1a1, AADC, TH nor DAT positive staining was observed in undifferentiated or differentiated AFS cells (Table 2), unlike other stem cell derivatives studied in our laboratory [3,6,14,18].

We next sought to determine whether transplantation of hAFS cells into the brain would further foster their development into DA neurons. Thus, undifferentiated $(N=4)$ and semi-differentiated hAFS cells (cells semi-differentiated with bFGF in Protocol A; $N=2$ or neurospheres generated in Protocol $\mathrm{B} ; \mathrm{N}=8$ ) were transplanted into the striata of hemi-lesioned (6-OHDA) immunosuppressed rats on the denervated side. Fully differentiated cells were not used in transplantation experiments (i.e., Protocol A) because process-bearing neurons do not generally survive harvest and implantation. Of the 12 animals that were transplanted, only one graft of neurospheres (Protocol B) contained viable hAFS cells, as evidenced by the presence of the human nuclear antigen marker (HNA) (Fig. 4A), and only at their earliest time point examined (3 days after implantation). As shown in Fig. 4A, surviving cells exhibited an immature morphology, expressing markers of neural progenitors (nestin; Fig. $4 \mathrm{~A})$ and neurons ( $\beta$-tubulin III) but not DA neuron traits (Lmx1a or TH; data not shown). Importantly, when grafts of these same cells were examined at 3 weeks after implantation, no hAFS cells remained at the implantation site (note the absence of HNA staining in Fig. 4B) nor were $\mathrm{HNA}^{+}$cells found in surrounding brain regions. Residual nestin staining observed in the vicinity of the graft was instead likely due to the presence of host brain progenitors. When these brains were further examined for the presence of reactive glia and macrophage/microglia, we found copious staining for their respective type-specific markers, GFAP and CD11 in host cells adjacent to the graft site at 3 days (data not shown) and 3 weeks (Fig. 4C and D) after implantation.

\section{Discussion}

This study has examined hAFS cells as an abundant, practical, and ethical source of stem cells to generate neurons for cell replacement therapies. In particular, our laboratory is interested in the differentiation of hAFS cells into functional DA neurons to replace cells lost in PD. We show here that undifferentiated hAFS cells from established cells lines [17] constitutively expressed mRNAs and proteins typical of stem cells but also cell derivatives of all three germ layers, including neural progenitors/neurons (nestin, $\beta$-tubulin III, NEFH). Additionally, these undifferentiated cells expressed specific transcripts appropriate to an immature DA phenotype (Lmx1a, Pitx-3, Nurr1, Aldh1a1). However, treatment of hAFS cells with various DA differentiation factors using a number of published protocols did little to advance their development into fully differentiated DA neurons. Only cells grown as neurospheres and differentiated as described in Protocol B exhibited an increase in the expression of some DA transcripts. When AFS neurospheres were transplanted in vivo, cells did not survive more than several days following their transplantation into the PD rat brain, likely due to an intense immunorejection response in host tissue. Transplanted cells that did survive in the short term, however, did not express detectable levels of any of DA proteins (Lmx1a, Aldh1a1, AADC, TH, DAT).

The fact that hAFS cells, even after incubation with known neuron-promoting differentiation factors [3-14,20], continued to express transcripts of non-neuronal cell types indicates that hAFS cells behave quite differently from other pluripotent stem cell sources. Thus, hES cells that initially express transcripts from all three germ layers, if grown under the same conditions used here (Protocol B), will proceed down a neural progenitor pathway to selectively become neurons [4-14]. Likewise, adult stem cells (hMSCs) grown under similar culture conditions (Protocol A) downregulate mesenchymal (FN) transcripts with the expression of neuronal markers (nestin, $\beta$-tubulin III) $[3,20]$. In contrast, in this study, undifferentiated hAFS cells expressed 

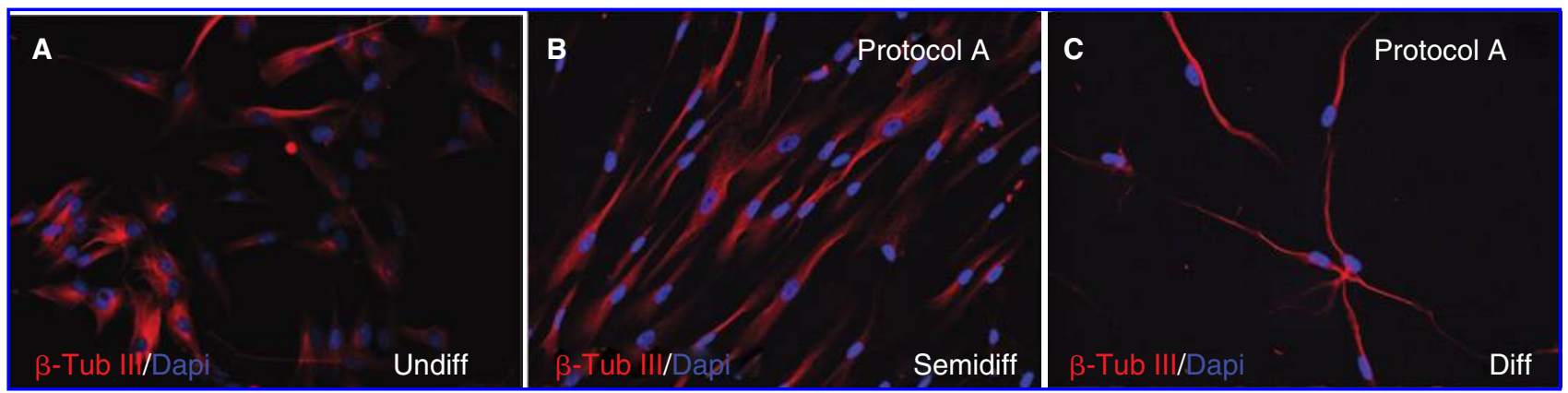

FIG. 3. Immunocytochemical localization of $\beta$-tubulin III in amniotic fluid stem (AFS) cells at various stages of differentiation. AFS cells were stained with $\beta$-tubulin III antibodies in the undifferentiated (Undiff) state (A) or after semi-differentiation (Semidiff) (B) and full differentiation (Diff) (C) using procedures described in Protocol A (as shown in Fig. 1). While many cells express $\beta$-tubulin III in all stages, unseen in imaged fields are other cells which do not express the neuronal marker. Note the change in cell shape as cells become more differentiated.

transcripts for nestin, $\beta$-tubulin III and FN, with no shift in the mRNA expression profile toward a neuronal fate after further differentiation in culture. Although differentiated hAFS cells acquired a neuronal like appearance and stained for neuronal marker proteins, it remains uncertain whether these cells can in fact function as neurons.

Further distinguishing the behavior of hAFS cells from other stem cell types was their acquisition of DA traits. Earlier studies on hMSCs and hES cells demonstrated that DA-related markers that were absent in undifferentiated cells could be partially or fully induced in vitro and in vivo using Protocols A and B, respectively [3,6,14,20]. In contrast, in this study, even in the undifferentiated state, hAFS cells expressed a number of mRNAs normally associated with DA-specified progenitors/neurons but could not be further induced to complete their DA differentiation by incubation using published protocols (Table 2). Although in Protocol B, neurosphere cells did not survive plating and growth on differentiation medium in order to assess DA protein expression, using Protocol A (and other differentiation schemes) there was no immunocytochemical evidence for Lmx1a, Aldh1a1, AADC, TH, or DAT in these cells, regardless of their differentiation status or their expression of DA mRNAs. The reasons for this disparity remain unknown but suggest that cells may be trapped in a primitive state, unable to produce critical proteins of a differentiated neuronal subtype using these treatment protocols. Consistent with this possibility is the fact that mature DA phenotypic traits, such as the expression of the key DA rate-limiting enzyme $\mathrm{TH}$ or the second enzyme in DA biosynthesis AADC, were never observed at either the transcriptional or protein levels in these cells. Nonetheless, the DA-associated Girk2 channel [21-23] was detected by RT-PCR both in this study and by Atala and colleagues who also demonstrated its functionality (i.e., barium sensitivity) in culture [17]. As Girk2 expression has also been reported in a variety of non-DA neurons [24-26), proof that its expression here represents the acquisition of a bona fide DA neuronal trait will require experimental corroboration by other methods. Additionally, using different AFS lines and a different DA differentiation protocol, Tsai et al. [27]
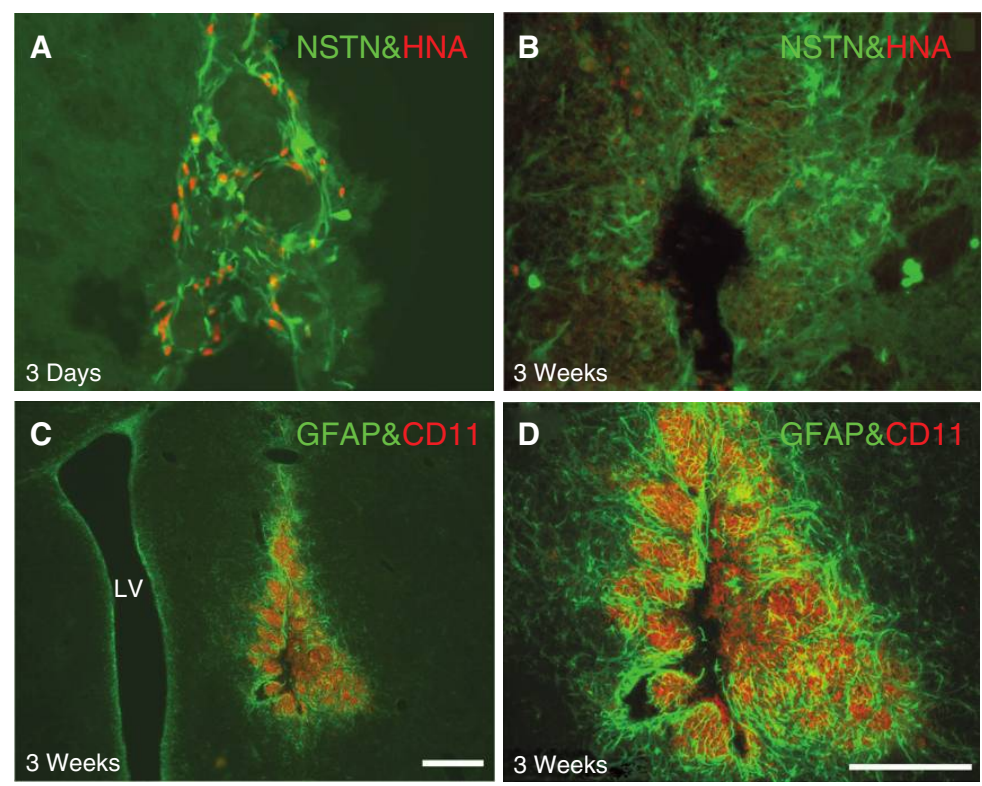

FIG. 4. Immunocytochemical localization of phenotypic markers at various times after transplantation of amniotic fluid stem (AFS) neurospheres into the striata of 6-OHDA treated rats. Cells were double labeled for: nestin and HNA at 3 days (A) and nestin and HNA (B) or GFAP and CD11 (C and D) at 3 weeks after transplantation. Panel D is a higher power view of the graft site shown in Panel C. Sections were mounted in ProLong Gold antifade reagent with DAPI (Invitrogen) and analyzed along the length of the graft using a NikonScanalytics Image System or a Zeiss LSM510 Confocal Image System. Bars $=100 \mu \mathrm{M}$. 
showed that small quantities of DA could be detected in the media following $\mathrm{KCl}$-stimulated release. However, they did not provide evidence that AFS cells possessed the DA synthetic machinery ( $\mathrm{TH}, \mathrm{AADC}$ ) to manufacture $\mathrm{DA}$ as opposed to simply taking up and re-releasing DA found in their (serum-containing) media.

Although the initial report describing these hAFS lines reported long-term survival of cells after transplantation into the lateral ventricles of newborn mice [17], in our transplantation studies, hAFS cells did not persist in the adult PD rat brain. This was likely due to the acute immunorejection of cells as evidenced by the copious expression of the microglial/macrophage marker CD11 and the reactive glial marker GFAP in host cells near the site of transplantation. This rejection response occurred despite the immunosuppression of rats with Cyclosporin A using a regimen that has successfully supported the long-term survival of other xenotransplanted human stem cells [3,6,14]. Similar to our observations, others using the same cell lines, also found an intense immunorejection response after hAFS transplantation into the immunosuppressed and immunodeficient rat myocardium [28]. Although hAFS cells were originally thought to be non-immunogenic because of their lack in major histocompatibility complex class II molecules, there is now evidence for expression of T-cell co-stimulatory molecules (normally found on antigen presenting cells) that may contribute to their immunorejection after transplantation [28]. Possibly, as a result of the relative immaturity of the newborn immune system, these molecules are less effective thereby allowing the survival of transplanted hAFS cells into the perinatal brain [17]). Another possible explanation for the rejection of these cells may stem from their heterogeneity, with mesodermal derivatives causing an intense immune/inflammatory response in the brain [3]. Of the few cells that did survive in the short term after transplantation into the brain, there was little evidence of maturation into fully differentiated neurons or incorporation into surrounding host tissues. A similar lack of neuronal differentiation and integration has recently been observed following the transplantation of human cord blood into the retina [29].

In sum, our studies have demonstrated that although hAFS cells constituitively express a number of traits normally associated with neural progenitors/immature neurons, they cannot be induced to acquire a fully differentiated DA neuronal phenotype in vitro or in vivo. In addition, these cells are highly immunogenic, inducing an acute rejection response after transplantation into the adult immunosuppressed rat brain. Taken together, these results suggest that further studies will be needed to improve differentiation procedures in culture and to prolong cell survival in vivo if hAFS cells are to be useful as replacement cells in PD therapy.

\section{Acknowledgments}

We are grateful to Emily Foran for her dedicated assistance in the tissue culture studies. This work was generously supported by a Michael J. Fox Foundation Rapid Response grant.

\section{References}

1. Lindvall O and A Bjorklund. (2004). Cell therapy in Parkinson's disease. NeuroRx 1:382-393.
2. Snyder BJ and CW Olanow. (2005). Stem cell treatment for Parkinson's disease: an update for 2005. Curr Opin Neurol 18:376-385.

3. Suon S, M Yang and L Iacovitti. (2006). Adult human bone marrow stromal spheres express neuronal traits in vitro and in a rat model of Parkinson's disease. Brain Res 1106:46-51.

4. Ben-Hur T, M Idelson, H Khaner, M Pera, E Reinhartz, A Itzik and BE Reubinoff. (2004). Transplantation of human embryonic stem cell-derived neural progenitors improves behavioral deficit in Parkinsonian rats. Stem Cells 22:1246-1255.

5. Buytaert-Hoefen KA, E Alvarez and CR Freed. (2004). Generation of tyrosine hydroxylase positive neurons from human embryonic stem cells after coculture with cellular substrates and exposure to GDNF. Stem Cells 22:669-674.

6. Iacovitti L, AE Donaldson, CE Marshall, S Suon and M Yang. (2007). A protocol for the differentiation of human embryonic stem cells into dopaminergic neurons using only chemically defined human additives: studies in vitro and in vivo. Brain Res 1127:19-25.

7. Itsykson $\mathrm{P}, \mathrm{N}$ Ilouz, $\mathrm{T}$ Turetsky, RS Goldstein, MF Pera, I Fishbein, M Segal and BE Reubinoff. (2005). Derivation of neural precursors from human embryonic stem cells in the presence of noggin. Mol Cell Neurosci 30:24-36.

8. Li Y, S Powell, E Brunette, J Lebkowski and R Mandalam (2005). Expansion of human embryonic stem cells in defined serumfree medium devoid of animal-derived products. Biotechnol Bioeng 91:688-698.

9. Park S, KS Lee, YJ Lee, HA Shin, HY Cho, KC Wang, YS Kim, HT Lee, KS Chung, EY Kim and J Lim. (2004). Generation of dopaminergic neurons in vitro from human embryonic stem cells treated with neurotrophic factors. Neurosci Lett 359:99-103.

10. Sonntag KC, J Pruszak, T Yoshizaki, J van Arensbergen, $R$ Sanchez-Pernaute and O Isacson. (2007). Enhanced yield of neuroepithelial precursors and midbrain-like dopaminergic neurons from human embryonic stem cells using the bone morphogenic protein antagonist noggin. Stem Cells 25:411-418.

11. Park $\mathrm{CH}$, YK Minn, JY Lee, DH Choi, MY Chang, JW Shim, JY Ko, HC Koh, MJ Kang, JS Kang, DJ Rhie, YS Lee, H Son, SY Moon, KS Kim and SH Lee. (2005). In vitro and in vivo analyses of human embryonic stem cell-derived dopamine neurons. I Neurochem 92:1265-1276.

12. Perrier AL, V Tabar, T Barberi, ME Rubio, J Bruses, N Topf, NL Harrison and L Studer. (2004). Derivation of midbrain dopamine neurons from human embryonic stem cells. Proc Natl Acad Sci USA 101:12543-12548.

13. Zeng X, J Cai, J Chen, Y Luo, ZB You, E Fotter, Y Wang, B Harvey, T Miura, C Backman, GJ Chen, MS Rao and WJ Freed. (2004). Dopaminergic differentiation of human embryonic stem cells. Stem Cells 22:925-940.

14. Cai J, AE Donaldson, M Yang, M German, G Enikolopov and L Iacovitti. (2008) The Role of Lmx1a in the differentiation of human embryonic stem cells into midbrain dopamine neurons in culture and after transplantation into a Parkinson's disease model. Stem Cells (Epub ahead of print).

15. Miki T, T Lehmann, H Cai, DB Stolz and SC Strom. (2005). Stem cell characteristics of amniotic epithelial cell. Stem Cells 23:1549-1559.

16. Mimeault M, R Hauke, and SK Batra. (2007). Stem Cells: a revolution in therapeutics-recent advances in stem cell biology and their therapeutic applications in regenerative medicine and cancer therapies. Nature 82:252-264.

17. Di Coppi P, G Bartsch, MM Siddiqui, $\mathrm{T}$ Xu, CC Santos, L Perin, G Mostoslavsky, AC Serre, EY Snyder, JJ Yoo, ME Furth, S Soker and A Atala. (2007) Isolation of amniotic stem cell lines with potential for therapy. Nature Biotech 25:100-106.

18. Yang M, AE Donaldson, CE Marshall, J Shen and L Iacovitti. (2004). Studies on the differentiation of dopaminergic traits in human neural progenitor cells in vitro and in vivo. Cell Transplant 13:535-547. 
19. Guo Z, ND Stull and L Iacovitti. (1998). Molecular mechanisms underlying the synergistic induction of tyrosine hydroxylase gene expression by acidic fibroblast growth factor and co-activators. J Neuroscience 18:8163-8174.

20. Suon S, H Jin, AE Donaldson, EJ Caterson, RS Tuan, G Deschennes, CE Marshall and L Iacovitti. (2004). Adult human bone marrow stem cells transiently differentiate in culture to express CNS proteins. Stem Cells Dev 13: 625-635.

21. Blum M, C Weickert and E Carrasco. (1999). The weaver GIRK2 mutation leads to decreased levels of serum thyroid hormone: characterization of the effect on midbrain dopaminergic neuron survival. Exp Neurol 160:413-424.

22. Chung CY, H Seo, KC Sonntag, A Brooks, L Lin and O Isacson. (2005). Cell type-specific gene expression of midbrain dopaminergic neurons reveals molecules involved in their vulnerability and protection. Hum Mol Genet 14:1709-1725.

23. Thompson L, P Barraud, E Andersson, D Kirik and A Björklund. (2005). Identification of dopaminergic neurons of nigral and ventral tegmental area subtypes in grafts of fetal ventral mesencephalon based on cell morphology, protein expression, and efferent projections. J Neurosci 25:6467-6477.

24. Aguado C, J Colón, F Ciruela, F Schlaudraff, MJ Cabañero, C Perry, M Watanabe, B Liss, K Wickman and R Luján. (2008). Cell type-specific subunit composition of $\mathrm{G}$ protein-gated potassium channels in the cerebellum. J Neurochem 105:497-511.

25. Best TK, M Cho-Clark, RJ Siarey and Z Galdzicki. (2008) Speeding of miniature excitatory post-synaptic currents in Ts65Dn cultured hippocampal neurons. Neurosci Lett 438: 356-361.

26. Sosulina L, G Schwesig, G Seifert and HC Pape. (2008). Neuropeptide Y activates a G-protein-coupled inwardly rectifying potassium current and dampens excitability in the lateral amygdala. Mol Cell Neurosci 39:491-498.

27. Tsai M-S, S-M Hwang, Y-L Tsai, F-C Cheng, J-L Lee and Y-J Chang. (2006) Clonal amniotic fluid-derived stem cells express characteristics of both mesenchymal and neural stem cells. Biol Reprod 74: 545-551.

28. Chiavegato A, S Bollini, M Pozzobon, A Callegari, L Gasparotto, J Taiani, M Piccoli, E Lenzini, G Gerosa, I Vendramin, E Cozzi, A Angelini, L Iop, GF Zanon, A Atala, P De Coppi and S Sartore. (2007). Human amniotic fluid-derived stem cells are rejected after transplantation in the myocardium of normal, ischemic, immuno-suppressed or immuno-deficient rat. J Mol Cell Cardiol 42:746-759.

29. Hill AJ, I Zwart, H Tam, J Chan, C Navarrete, LS Jen and R Navarette. (2008) Human umbilical cord blood-derived mesenchymal stem cells do not differnetiate into neural cell types or integrate into the retina after intrvitreal grafting in neonatal rats. Stem Cell and Develop (Epub ahead of print).

Address correspondence to: Dr. Lorraine Iacovitti Farber Institute for the Neurosciences Thomas Jefferson University Philadelphia, PA 19107

E-mail: lorraine.iacovitti@jefferson.edu

Received for publication October 6, 2008

Accepted after revision December 1, 2008 Prepublished on Liebert Instant Online December 2, 2008 



\section{This article has been cited by:}

1. Weerapong Prasongchean, Marinella Bagni, Cinzia Calzarossa, Paolo De Coppi, Patrizia Ferretti . 2012. Amniotic Fluid Stem Cells Increase Embryo Survival Following Injury. Stem Cells and Development 21:5, 675-688. [Abstract] [Full Text HTML] [Full Text PDF] [Full Text PDF with Links]

2. Roberto Soler, Claudius Füllhase, Ariel Hanson, Lysanne Campeau, Cesar Santos, Karl-Erik Andersson. 2012. Stem Cell Therapy Ameliorates Bladder Dysfunction in an Animal Model of Parkinson Disease. The Journal of Urology . [CrossRef]

3. Petra AB Klemmt, Vida Vafaizadeh, Bernd Groner. 2011. The potential of amniotic fluid stem cells for cellular therapy and tissue engineering. Expert Opinion on Biological Therapy 1-18. [CrossRef]

4. M. Rosner, M. Mikula, A. Preitschopf, M. Feichtinger, K. Schipany, M. Hengstschläger. 2011. Neurogenic differentiation of amniotic fluid stem cells. Amino Acids . [CrossRef]

5. Sarah Decembrini , Mara Cananzi, Sara Gualdoni, Alysia Battersby, Nick Allen, Rachael A. Pearson, Robin R. Ali, Paolo De Coppi , Jane C. Sowden . 2011. Comparative Analysis of the Retinal Potential of Embryonic Stem Cells and Amniotic Fluid-Derived Stem Cells. Stem Cells and Development 20:5, 851-863. [Abstract] [Full Text HTML] [Full Text PDF] [Full Text PDF with Links] [Supplemental material]

6. Stefano Da Sacco, Roger E De Filippo, Laura Perin. 2011. Amniotic fluid as a source of pluripotent and multipotent stem cells for organ regeneration. Current Opinion in Organ Transplantation 16:1, 101-105. [CrossRef]

7. Mara Cananzi, Anthony Atala, Paolo de CoppiStem Cells from Amniotic Fluid 223-239. [CrossRef]

8. D. A. Davydova. 2010. Stem cells in human amniotic fluid. Biology Bulletin 37:5, 437-445. [CrossRef]

9. Shona Pfeiffer, David McLaughlin. 2010. In vitro differentiation of human amniotic fluid-derived cells: augmentation towards a neuronal dopaminergic phenotype. Cell Biology International 34:9, 959-967. [CrossRef]

10. Jingli Cai , Ming Yang, Elizabeth Poremsky, Sarah Kidd, Jay S. Schneider, Lorraine Iacovitti . 2010. Dopaminergic Neurons Derived from Human Induced Pluripotent Stem Cells Survive and Integrate into 6-OHDA-Lesioned Rats. Stem Cells and Development 19:7, 1017-1023. [Abstract] [Full Text HTML] [Full Text PDF] [Full Text PDF with Links] 